\title{
Introduction: The Western Concept of Childhood
}

\author{
Laurence Brockliss
}

As the great European powers, and to a lesser extent the United States, became predominant commercially and militarily across the globe after $185^{\circ}$, the rest of the world came to see Western culture in all its many different forms as an ideal that had to be imitated and absorbed if colonization and domination by outsiders were ever to be overthrown or withstood. This was as true of conceptions of childhood and child-rearing as anything else. In the Middle Ages European children had been largely seen as fallen, wilful and incomplete creatures whose socialization into adulthood was left to their parents and was a matter of custom. By the late nineteenth century, among most of the well-todo at least, children were seen as fragile, innocent vessels: their upbringing required expert advice to be successfully negotiated and was the responsibility of the state as well as the family. ${ }^{1}$ Any history of children and child-rearing in the non-Western world in the late nineteenth and early twentieth centuries will inevitably have as its backdrop the impact of this still freshly minted idea of childhood on traditional beliefs and practices. At the same time, the influence of Western ideas on any narrative of non-Western childhoods in the decades before and after the First World War will be far from straightforward. Importing the Western concept of childhood into traditional societies and cultures was inevitably a Herculean task. The supporters of modernization usually lacked the money and the authority to enforce their will, while many of the modernizers were understandably ambivalent about unreservedly introducing the alien ideas of the imperialists into their native land, even if they believed there was a need to re-structure traditional beliefs. The Western concept of childhood, moreover, was not frozen in aspic. The West's child-centred concept of childhood which began to command the world's attention in the course of the second half of the nineteenth century was itself continually being developed, refined and contested.

According to the French historian Philippe Ariès, who is generally regarded as the father of the modern history of childhood, this child-centred concept of childhood began to develop in the seventeenth century when the division of

1 For an overview, see Colin Heywood, A History of Childhood: Children and Childhood in the West from Medieval to Modern Times (Cambridge: Polity Press, 2001). For the singularity of modern Western childhood, see Peter Stearns, Childhood in World History (Abingdon: Routledge, 2006).

(C) LAURENCE BROCKLISs, 2016 | DOI 10.1163/9789004305809_002

This is an open access title distributed under the terms of the Creative Commons Attribution- 
Christendom in the wake of the Reformation led the new Protestant and Counter-Reformation Churches to place a novel emphasis on the creation of godly laity. As he argued in his pioneering work, L'Enfant et la Vie Familiale sous l'Ancien Régime, published in 1960, it was only then that young children, even at the top of the social ladder, were given their own separate space and no longer mixed promiscuously with adults, playing the same games and picking up at an early age a rich vocabulary and interest in sex. It was in this century, too, that it first became common for a growing section of the population, even for artisans' and peasants' children, to spend part of their day in school being 'civilized' as well as taught to read and write. ${ }^{2}$ The seventeenth century, however, was only the beginning of the story, as later historians have realized. The concept of childhood as an age of innocence was the creation of the following century and was the product of the Age of Enlightenment. In the eighteenth century a growing number of intellectuals followed John Locke in breaking with the traditional Christian idea of original sin-if not necessarily with Christianity — and declared that the new-born infant was a tabula rasa whose development into a socialized adult depended entirely on the environment in which he or she was raised. Jean-Jacques Rousseau, in his educational novel Émile (1762), took the new idea a stage further by claiming that a child's rational capacity hardly developed before puberty, so that new experiential ways had to be devised in order to teach younger children the basic life skills, and book- and rote-learning had to be abandoned. ${ }^{3}$ Novelists and poets, too, not just philosophers, were won to the idea that children were empty vessels who could be made or marred by their parents. The melancholic began to look back to their childhoods to explain their deficiencies as adults, ${ }^{4}$ and by the end of the century William Blake was claiming childhood was an age of bliss and innocence easily ruined by heartless parents only interested in their economic potential, not their happiness. ${ }^{5}$

2 The work was translated into English two years later as Philippe Ariès, Centuries of Childhood: A Social History of Family Life (London: Jonathan Cape, 1962). Ariès's more radical assertions that parents in the Middle Ages did not love or cherish their children has been largely dismissed by medievalists: e.g. Shulamith Shahar, Childhood in the Middle Ages (London: Routledge, 1990).

3 For a recent account of Locke and Rousseau's educational theories, see Natasha Gill, Educational Philosophy in the French Enlightenment: From Nature to Second Nature (Farnham: Ashgate, 2010).

4 Sebastian Matzner, "Haunted by Paradise Lost: The Theme of Childhood in EighteenthCentury Melancholy Writing," Childhood in the Past, 1, 2008, 120-135.

5 E.g. "The Chimney Sweeper," from Songs of Experience (1794). 
The Enlightenment's emphasis on getting child-rearing right encouraged the development of a novel child-centred material culture of books, games and even dress (to ensure growing limbs would not be constrained by the adult fashion for stays and corsets). ${ }^{6}$ In the richer European states in the course of the nineteenth century this became a highly profitable industry, legitimized by a new generation of Rousseauvian educational theorists, such as the Swiss Johann-Heinrich Pestalozzi and the German Friedrich Froebel, who taught that children in their early years learnt most effectively through controlled play. ${ }^{7}$ There was a growing feeling too as the century wore on that artefacts especially created for children should not just be learning aids but objects to heighten the simple joy of being a child. Building on the nostalgic notion promoted by Wordsworth and other Romantics that childhood was potentially a special time of quasi-divine understanding lost in becoming adult, a number of novelists, educational theorists and proto-child psychologists took the Enlightenment theory of childhood one stage further. Growing up should be fun: children were entitled to a happy and not just a properly ordered upbringing and should be allowed to dwell in their own magical universe as long as possible. ${ }^{8}$ At the same time, many of the same pundits were also convinced that for even the conscientious parent child-rearing was a hazardous activity. The publication of Darwin's On the Origin of Species in 1859 had as profound an effect on contemporary theories of childhood as it had on other areas of the burgeoning social sciences. It became fashionable to believe that the development of the individual child mirrored the history of the human race in its rise from primitive simian beginnings to the heights of Western civilization. According to the American educationalist and psychologist G. Stanley Hall, writing in 1904, this made the teenage years particularly difficult to negotiate successfully, for it was then that children of all classes had to learn to subsume their emotions under their reason. This inevitably led to inner turmoil, which could only be quieted by the most careful parental oversight. The slightest wrong turn and the teenager would fail to mature into a civilized adult.

6 Children's literature has been particularly well researched: e.g. Matthew Grenby, The Child Reader, 1700-1840 (Cambridge: Cambridge University Press, 2011). For an early analysis, see J. H. Plumb, "The New World of Children in Eighteenth-century England," Past and Present, $67,1975,64-95$.

7 Pestalozzi (1746-1827) set up an experimental school at Yverdon in 1805; Froebel (1782-1852) invented the kindergarten, a term he coined in 1840 for the play and activity institute for young children he had set up at Bad Blankenberg in 1837 .

8 Wordsworth's nostalgia for childhood was set out in his book-length autobiographical poem, The Prelude (1805). 
Successful parenting was a science: it was next to impossible without expert external advice. ${ }^{9}$

The belief that childhood was precious but parenting difficult was widely disseminated among the well-to-do in the Western world in the second half of the nineteenth century. In England the rapid spread of public and preparatory boarding schools after 1850 was not a sign of the heartlessness of middle-class Victorian parents but stemmed rather from fears they were too indulgent to oversee their sons' passage from their idyll of childhood to the harsh realities of adult life. Someone else was needed to give their offspring the necessary sharp shock. ${ }^{10}$ Nonetheless, the new ideas about child-rearing did not command universal consent by the end of the nineteenth century, even among the well-to-do. Pre-Enlightenment views of children as fallen and wilful who needed to be beaten into righteousness continued to be embraced by the traditionalist wings of the Catholic and Protestant Churches. Many high- as well as low-born children were brought up 'by hand' like Dickens's Pip in Great Expectations and Samuel Butler's Ernest Pontifex, thrashed on one occasion for failing to pronounce the word 'come' properly. ${ }^{11}$

Nor did the new understanding of childhood initially receive much support from the state. For the most part, the novel stadial theories of child development were the creation of free-thinking radicals, who had little influence over government policy in Britain, France and Germany. The nineteenth-century state was not unconcerned with the fate of children. Long before Locke and Rousseau, the state had acknowledged the need to step in when parents or those in loco parentis maltreated or neglected children in their care. But the authorities only did so, as they had in the past, in the most egregious circumstances. The nineteenth-century state was also not oblivious to calls in the wake of industrialization that children should be protected from exploitation

G. Stanley Hall, Adolescence: Its Psychology and Its Relations to Physiology, Anthropology, Sociology, Sex, Crime and Religion (New York: D. Appleton and Company, 1904). For a detailed account of theories of child development in Britain in the decades before the First World War, see Sally Shuttleworth, The Mind of the Child: Child Development in Literature, Science and Medicine, 1840-1900 (Oxford: Oxford University Press, 2010).

10 Boys who were not sent to public school were thought to grow up as sissies: see Cuthbert Bede, The Adventures of Verdant Green (Oxford: Oxford Paperbacks, 1982 [1853-1857]), especially 6-7.

11 The Way of All Flesh (Harmondsworth: Penguin, 1966 [1903]), 125. The novel was a fictionalized account of Butler's own childhood. Girls as well as boys could be physically punished for their own good; in 1855 a French governess, Célestine Doudet, was found guilty of torturing five English sisters, on their father's behest, in order to prevent them from masturbating. 
in the factories and mines. But the passage of legislation banning the very young from long hours of arduous and monotonous labour was seldom evidence of the power of the new ideas in national legislatures. In Britain the first child labour laws in the 1830 s and 1840 os were the result of the lobbying of traditional evangelical Christians, like the Earl of Shaftesbury, who objected to the balance-sheet mentality of the new entrepreneurs and believed masters should have a paternalistic care for their workers. ${ }^{12}$ Even in 1885 , when Parliament struck the first blow against child prostitution by raising the age of consent to sixteen, the leaders of the campaign for change, W.T. Stead of The Times and Josephine Butler, were fervent Christians. ${ }^{13}$

The nineteenth-century state, to the extent it had a position on childhood, embraced an Enlightened not a Romantic agenda. The philosophes in the eighteenth century believed that it would be possible to turn every child into a productive and law-abiding citizen/subject if the state set up a system of universal elementary education where the offspring of the poor majority, girls as well as boys, would be taught to read, write and count and learn right from wrong. ${ }^{14}$ A few eighteenth-century rulers, notably Frederick the Great of Prussia, paid lip-service to this agenda but most were content to leave what provision of elementary education there was to the church. ${ }^{15}$ The upheaval wrought by the French Revolution and the subsequent Revolutionary and Napoleonic Wars led the rulers of Europe after 1815 to reconsider their position. The French revolutionaries themselves had understood that the safety of the Revolution depended on taking the next generation out of the family and schooling it in the new values of the rights of man, but they lacked the money in wartime to make their dream a reality. ${ }^{16}$ The redrawing of the map of Europe at the Congress of Vienna created a congeries of states filled with people of different religious and ethnics backgrounds who had never had to live together hitherto. Compulsory universal education now seemed the key to effective

12 In France, too, it was religious traditionalists and paternalists who affected change: see Lee Shai Weisbach, Child Labour Reform in the Nineteenth-century France: Assuring the Future Harvest (Baton Rouge: Louisiana State University Press, 1989).

13 Louise Jackson, Child Sexual Abuse in Victorian England (London: Routledge, 200o).

14 For the debate in France, see Harvey Chisick, The Limits of Reform in the Enlightenment: Attitudes towards the Education of the Lower Classes in Eighteenth-century France (Princeton: Princeton University Press, 1981).

15 Even in Prussia, it was the Lutheran church which maintained the system of elementary education which Frederick promoted: Wolfgang Neugebauer, Absolutistischer Staat und Schulwirklichkeit in Brandenburg-Preussen (Berlin: De Gruyter, 1985).

16 Han-Christian Harten, Elementarschule und Pädagogik in der Französischen Revolution (Munich: R. Oldenbourg, 1990). 
state-building for all regimes, be they liberal or conservative. Initially, in the 1820 s and 1830 , it was states that felt particularly insecure, such as Prussia and France, which set up a system of state-financed elementary schools. ${ }^{17}$ In Britain, on the other hand, only lightly touched by the upheavals on the continent, the state was happy to leave elementary education, as before, to the churches. It was only in Ireland, newly attached to the British state in 1801 and a potential source of unrest and disloyalty, that the government felt moved to establish a national system of education in the years following Catholic emancipation in $1829 .{ }^{18}$ Even Britain, however, had set up a universal state-system of sorts by 1880 , and by 1914 every European state-including Russia-had laid the foundations of a compulsory system, although the proportion of children between the ages of five to seven and 12 to 13 actually in school was in the poorest states relatively small. ${ }^{19}$ North America and other parts of the Englishspeaking world similarly set up their own system after 1860, though it was not until 1918 that the state of Mississippi made attendance de rigueur. ${ }^{20}$

The new compulsory systems of education set up in Europe and North America across the nineteenth century were scarcely dedicated to the promotion of the happy child. Their principal aim was to create literate, useful and law-abiding citizens who would love their native land and be ready to die for its sake. Corralled in desks for hours at a time, they were prisoners in a crowded class-room, taught by rote and punished, often by being beaten, for ignorance, disobedience and slovenliness. ${ }^{21}$ It was not until the end of the nineteenth century that the state began to evince an interest in the new ideas

17 For France, see Laura S. Strumingher, What Were Little Boys and Girls Made of? Primary Education in Rural France. 1830-1880 (Albany: State University of New York Press, 1983), and Raymond Grew and Patrick J. Harrigan, School, State, and Society: The Growth of Elementary Schooling in Nineteenth-century France: A Quantitative Analysis (Ann Arbor: University of Michigan Press, 1992).

18 Donald H. Akenson, The Irish Educational Experiment: The National System of Education in the Nineteenth Century (London: Routledge and Kegan Paul, 1970); Jane McDermid, The Schooling of Girls in Britain and Ireland, 1800-19oo (Abingdon: Routledge, 2012).

19 For Russia, see Jeffrey Brooks, When Russia Learnt to Read: Literacy and Popular Literature, 1861-1917 (Princeton: Princeton University Press, 1985) and Ben Eklof, Russian Peasant Schools: Officialdom, Village Culture and Popular Pedagogy (Berkeley: University of California Press, 1986).

20 For an overview, see Laurence Brockliss and Nicola Sheldon (eds), Mass Education and the Limits of State Building, c. 1870-1930 (Basingstoke: Palgrave Macmillan, 2012), 167-176, 251-260, and essays by Ellen Berg (the United States) and S. E. Duff (South Africa).

21 Work in progress by Sîan Pooley of Cambridge University suggests that in British schools at least children were not turned into knee-jerk jingoists; the emphasis was on inculcating a concept of fairness. See her "Leagues of Gentleness' and 'Column Comrades': Children's 
about child rearing and child development, as teaching became a profession whose practitioners underwent theoretical as well as classroom training and the inspectorate set up to monitor classroom performance was won over to child-centred learning. Even then the resultant changes in approach were limited. States were unwilling to commit the funds needed to make school life more fun, so 'chalk and talk' remained the predominant way of delivering the curriculum. In England before the First World War the principal evidence that the elementary-school curriculum was becoming more child-orientated lay in the new commitment to nature study, which aimed to teach pupils about their local environment through letting them draw specimens of flowers. $^{22}$

From the end of the nineteenth century, too, the state developed a new interest in children's bodies as well as their minds. There had always been children who had been abandoned or orphaned and had had to be brought up outside the family home in institutions run by the church or the local municipality. ${ }^{23}$ After 1870 , however, the state began to claim the right to take children away from their family home in cases of parental neglect or inadequacy and place them in special orphanages where they would be brought up properly. ${ }^{24}$ The primary concern was moral: bad parents threatened to undermine the good work of the elementary schools by the example they set their offspring. But intervention was also fired by a growing concern about child abuse and the physical well-being of the nation's young, which was connected to a wider worry at the turn of the twentieth century about the poor physical state of the working-classes sparked by the new interest among those studying child

Responses to War in Late-Victorian and Edwardian England," in Lissa Paul and Rosemary Johnston (eds), Children and the Great War: 1890-1919 (forthcoming).

22 For an example of a nature study lesson, see the account in D. H. Lawrence, Women in Love (1921), Chapter Three (Lawrence had been a teacher himself).

23 For an introduction, see the works listed at Oxford Bibliographies on Childhood Studies for Western Europe and Scandinavia: http://www.oxfordbibliographies.com/view/ document/obo-9780199791231/obo-9780199791231-0o18.xml. Large numbers of children were abandoned in the pre-modern era, in nineteenth century Paris up to $20 \%$ of all babies born: Rachel G. Fuchs, Abandoned Children: Foundlings and Child Welfare in Nineteenth-Century France (Albany: sunY Press, 1984). In England, too, children of poor parents forced to seek shelter in the workhouse were temporarily at least separated from their mothers and fathers.

24 In Britain special boarding-schools were created on ships and in the countryside where neglected children could be rehabilitated: see Nicola Sheldon, "Socialising the Anti-Social Youth: Industrial Schools and Citizenship," paper presented at the Institute of Historical Studies, January 28, 2010. 
development in correlating children's age, height and weight. ${ }^{25}$ In part, the state was moved to act by new lobby groups like the National Society for the Prevention of Cruelty to Children, established in 1895 out of a number of local organizations active from the early 1880 s. $^{26}$ But it also had its own agenda. In the case of boys the state was fearful lest the army of the future would be staffed by weaklings. In the case of girls, it feared that the national stock would be depleted if they grew up into underweight, listless mothers unable to produce healthy babies and unable to look after them properly. In England, where the government was shocked by the physical state of soldiers recruited during the Boer War and eugenicist ideas were widely embraced by the country's opinion formers, it was quickly decided that the elementary school must extend its remit. Physical education, especially team games, became a part of the official school day, while in 1906 Parliament passed a School Meals Bill which empowered local authorities to provide a hot midday meal for the neediest children and in 1907 it created a nationwide school medical service financed through the local rates. ${ }^{27}$

After the First World War, the European states' role as a surrogate parent was further extended. In most countries compulsory education continued to end with elementary school. Until 1945 few states thought more than $10 \%$ of children would benefit from secondary schooling and provided scant opportunity

25 The science of pedology was particularly developed in Belgium and France, where it was believed that it was the key to producing well-educated children; elementary education would be wasted if children were too under-nourished or tired to learn. A leading figure of the movement in the first decade of the twentieth century was the Belgium-based Polish paediatrician Jozefa Joteyko. See Ilana Lowy, "Measures, Instruments, Methods and Results': Jozefa Joteyko on Social Reforms and Physiological Measures," in Gérald Jorland, Annick Opinel and George Weicz (eds), Body Counts: Medical Quantification in Historical and Sociological Perspective/Quantification médicale: perspectives historiques et sociologiques (Montreal: McGill-Queen's University Press, 2005), 143-172.

26 It was the lobbying of the London Society that led to parliament passing Britain's first Prevention of Cruelty to Children Act in 1889: see Harry Hendrick, Child Welfare: England, 1872-1989 (London: Routledge, 1994).

27 On team games, see Susannah Wright, "Citizenship, Moral Education and the English Elementary School," in Brockliss and Sheldon, Mass Education, 30-31. For the introduction of school meals, see Harry Hendrick, Children, Childhood and English Society, 1880-1990 (Cambridge: Cambridge University Press, 1997), 47-48, 67. On girls' physical well-being, see Hilary Marland, Health and Girlhood in Britain, 1874-1920 (Basingstoke: Palgrave Macmillan, 2013). In Britain, teenage girls in the middle classes responded so positively to the call they should be physically active that by the outbreak of the First World War, there were concerns they were becoming too manly: the 'bicycling' girl was particularly worrying. 
for even clever working-class children to continue with their studies. ${ }^{28}$ The tutelary role of the state, however, was taken ever more seriously. In the new Soviet Union, where mothers were expected to work and most parents were suspect in their political loyalties, the state became a surrogate parent providing crèches as well as schooling and making membership of party-run youth organizations - the Young Pioneers and the Komosol (All-Union Leninist Young Communist League) —all but mandatory. ${ }^{29}$ In Western and Central Europe, state intervention was more restrained, and in many cases the state simply set the policy and left it to charities and voluntary bodies to provide the infrastructure and to the childcare experts to promote the cause of good parenting through advice literature and in the burgeoning periodical press. ${ }^{30} \mathrm{In}$ both France and Britain, for instance, there was widespread agreement among educationalists, child-psychologists and politicians in the interwar years that an unrelieved urban upbringing was physically and morally deleterious: all children should have the chance to enjoy the delights of the countryside. In consequence, in both countries every summer a large number of working-class children left their home environment to spend one or two weeks of the summer breathing the pure bucolic air of the countryside. In France, the colonies de vacances were organized by the government; in Britain the holidays were organized by specialist charities, such as the the Children's Country Holiday Fund, and the many youth organizations - the Boys' Brigade, Boy Scouts, Girl Guides and so on - which had sprung up on the eve of the First World War as part of the drive to create civic-minded and patriotic citizens of Empire. ${ }^{31}$

28 Brockliss and Sheldon, "Introduction," in id., Mass Education, 14-15 and 91-92 (some figures). The United States was different. By 1940, $49 \%$ of American teenagers would graduate from high school: Ellen Berg, "'To Become GOOD MEMBERS OF CIVIL SOcIETY and PATRIOTIC AMERICANS': Mass Education in the United States, 1870-1930," ibid., 92.

29 Catriona Kelly, Children's World: Growing Up in Russia, 1890-1991 (New Haven: Yale University Press, 2007). As in the United States, many working-class Soviet children were able to go on to secondary education in the 1930 and became totally loyal to the Soviet state in consequence.

30 In Britain, periodicals aimed at mothers and teenage girls were on the market from the turn of the twentieth century. So too were advice manuals. But they became ever more numerous after 1918, the year that saw the publication of first edition of the Stenhouses' Health Reader for Girls.

31 Laura Downs, Childhood in the Promised Land: Working-Class Movements and the Colonies de Vacances in France, 1880-1960 (Durham, NC: Duke University Press, 1960); Hester Barron, "Changing Conceptions of the 'Poor Child': The Children's Country Holiday Fund, 1918-1939," Journal of the History of Childhood and Youth (forthcoming); Tammy M. Proctor, On My Honour: Guides and Scouts in Interwar Britain (Philadelphia: American 
The developed world also invested children and childhood with greater dignity than ever before in the interwar years. Much had been made in Britain during the war of the German soldiers' inhumanity in their purported treatment of children..$^{32}$ Immediately after the war, the focus changed to the plight of children displaced or under-nourished in the wake of the conflict, and in 1919 the social reformer Eglantyne Jebb founded the Save the Children Fund, dedicated to helping victims of famine in Berlin and Austria, and which quickly became an international organization. Four years later, Jebb drew up the first ever Declaration of the Rights of the Child, which emphasized a child's right to a normal material and spiritual upbringing and its right not to be exploited:

The child that is hungry must be fed; the child that is sick must be nursed; the child that is backward must be helped; the delinquent child must be reclaimed; and the orphan and waif must be sheltered and succoured..$^{33}$

Adopted in 1924 by the new League of Nations, the declaration was the starting point for our present day concept of children's rights. A child's right to family life was particularly stressed, leading to a novel interest in finding caring homes for unwanted children rather than leaving them to languish in orphanages. In nineteenth-century Britain children had frequently been fostered or taken in but formal adoption had always been illegal. All this changed with the end of the war: private adoption agencies sprang up to deal with the unprecedented number of illegitimate babies and fatherless children, and in 1926 legalized adoption was allowed for the first time. ${ }^{34}$

What did not change dramatically over the interwar years was the orthodoxy on child-rearing. Late nineteenth-century child development theorists had been keen to emphasize that successful parenting demanded skill and time, but they had also preached that success depended on organization. A child subjected to a form of control and discipline appropriate to his or her age would emerge as a fully-rounded adult. One cosseted, arbitrarily or inconstantly

Philosophical Society, 2002). The history of childhood during the interwar years is only now beginning to receive serious attention.

32 This remains a contentious issue. For a discussion, James Morgan Read, Atrocity Propaganda, 1914-1919 (New Haven: Yale University Press, 1941).

The full text is available at http://www.un-documents.net/gdrc1924.htm. Clare Mulley, The Woman who Saved the Children: A Biography of Eglantyne Jebb Founder of Save the Children (Oxford: Oneworld, 2009).

34 Heather Montgomery, "Unwanted Children and Adoption in England," in Laurence Brockliss and Heather Montgomery (eds), Childhood and Violence in the Western Tradition (Oxford: Oxbow Books, 2010), 83-88. 
punished or treated inappropriately would be launched down the Primrose path. It was this 'behaviourist' view of child rearing that dominated establishment thinking until the 1940s. Although figures like Freud were questioning the value of 'tough love' and some child gurus were advocating allowing children to do as they like and find their own feet, their ideas had little purchase outside Soviet Russia in the 1920s where novel 'anti-bourgeois' philosophies of all kinds had a temporary hearing and Lev Vygotsky was developing his ideas of the role of the environment on children's cognitive development. ${ }^{35}$ Parents in the Western world in the first part of the twentieth century were supposed to love and look after their children; they were not supposed to cut them much slack. A change towards a much more child-focused theory of child-rearingone that stressed the differences between children and the special needs of the individual child — took root only in the years following the Second World War under the influence of the inter-war work of such seminal figures as the Swiss child psychologist Jean Piaget, the Austrian psycho-analyst Melanie Klein and the British educationalist Susan Isaacs, who stressed the importance of learning through child-directed play. ${ }^{36}$

The chapters in the present book bring out clearly how partial, fine and complex the imprint of Western theories of childhood and childhood development could be on movements for national reform and regeneration in nonWestern countries in the decades before and after the First World War. While it is evident that reformers, both Muslim and non-Muslim, in the old Ottoman Empire and the new states that emerged from its collapse had imbibed the Western message that the future strength and success of the state depended on turning children - girls as well as boys-into good citizens and patriots, there was no uniform response to the question: what should be done? Lack of resources was key. While Western states were often unwilling to commit taxpayers' money to the child problem, the Ottomans and their successors had very little to spend in the first place. Establishing state-controlled systems of education before the $1920 \mathrm{~s}$ was therefore next to impossible, and was sometimes not even attempted. The Bulgarians in the late nineteenth century left

35 Vygotsky (1896-1934) was little known outside Russia in his life time. His work only began to be seriously studied in the West in the 1970s. For his ideas and their eventual influence, see Peter E. Langford, Vygotsky's Developments and Educational Psychology (Hove: Psychology Press, 2005).

36 Schooling therefore remained very formal in the interwar years. Only a handful of private experimental schools such as A. S. Neill's Summerhill, initially established in Dresden in 1921 before moving to Lyme Regis, allowed children to learn in their own way and at their own pace. See Jonathan Croall, Neill of Summerhill: The Permanent Rebel (London: Routledge, Kegan and Paul, 1983). 
the task of national education to the army: in the absence of other institutions, conscription became the primary tool of state-building, albeit a highly imperfect one given the high proportion of males who escaped military service. ${ }^{37}$ As a result, child-rearing before 1918 remained almost exclusively the family affair it had always been. New ideas about childhood and citizen-formation were paraded in novels, travelogues and periodicals, but there were inevitable limits to their reach in an area of the world with low literacy. As a result, they tended to preach to the converted.

The promoters of the new ideas also delivered a mixed message. Postindependence Romanian nationalists, Janus-like, saw the new Romania in both the traditional village and the new city, while late-Ottoman educationalists were unclear whether children should be allowed a childhood or turned as quickly as possible into useful and independent adults: it seemed to depend on how far the Empire was felt to be in crisis. ${ }^{38}$ Egyptian intellectuals, on the other hand, living under British control at the beginning of the twentieth century, were anxious to dress Western ideas in Islamic clothes. As nationalists, they objected to the wealthy Anglophone elite bringing their children up on what was perceived as Western lines, and called for a child-rearing revolution which encouraged creativity and interactive learning, not because these were Western imports but because they were part of the forgotten Islamic inheritance. ${ }^{39}$ Intellectuals, too, could promote Western ideas of independence by reworking Islamic institutions. Fatma Aliye, the first Ottoman female novelist, was an ardent supporter of female education but she packaged her views in a traditional context. Her vision of the ideal school for girls was one where girls were taught there was more to life than marriage but where the gendered classroom mirrored the isolated but convivial society of the harem. ${ }^{40}$

After 1923, with the establishment of the new secular Turkish Republic devoted to rapid modernization, Western concepts of childhood and child rearing were inevitably championed more forcibly in the heartland of the old Ottoman Empire. The Kemalist regime was totally convinced that universal literacy had to be created as quickly as possible if Turkey were to become a

37 See the chapter by Kaytshev in this volume.

38 See the chapters by Drace-Francis and Fortna in this volume. Fortna is the author of a full length study of the attempt to establish state education at the end of the Ottoman era: Imperial Classroom: Islam, the State and Education in the Late Ottoman Empire (Oxford: Oxford University Press, 2002).

39 See the chapter by Morrison in this volume. Her argument is developed further in ead., Modernity Comes of Age: Childhood in Early Twentieth-Century Egypt (Basingstoke: Palgrave Macmillan, forthcoming).

See the chapter by Akșit in this volume. 
respected and powerful state, and many more resources were pumped into education both for adults and children. ${ }^{41}$ But the new Turkey continued to spread mixed messages about childhood. If the Kemalist state believed that children were the future, it did little to promote the idea that childhood was a time of innocence, and in its determination to create patriotic citizens was happy to sponsor children's magazines that filled young minds with stories and images of war and starvation. It was left to periodicals specifically aimed at mothers to promote a gentler, more child-focused view of childhood. Not surprisingly, then, the regime soon faced criticism from supporters of modernization, particularly socialists, who felt that the state, for all its rhetoric about children, was not doing enough to deal with child poverty and children's health. ${ }^{42}$

Autobiographical evidence, moreover, although sometimes of questionable reliability, suggests that before 1920 most childhoods were all but untouched by imported Western ideas. The centre of life was the household, a secure and protected space where children listened to folk tales and stories about their ancestors. ${ }^{43}$ Not surprisingly therefore the first generation of children who were subjected to state intrusion in their lives found the experience upsetting. Egyptian memoir writers, recounting their childhood, recalled how much they disliked having their bodies poked by doctors, or teachers telling them many of their ideas about spirits and jinns were superstitious and untrue. Children who were taken out of their traditional environment altogether and fully exposed to Westernization seem to have seldom thrived. During the First World War many orphans, usually in their mid-teens, were sent to Germany to be trained as apprentices: with a handful of exceptions the experience was unpleasant and many returned early.4 Before 1914, even children of fathers who were Ottoman bureaucrats and committed to modernization could have very different childhoods. Demetra Vaka and Selma Ekrem both came from families, one Christian and one Muslim, who believed that girls as well as boys should have an education. But Demetra, a Christian, was brought up in a disciplined environment were her nose was kept to the grindstone, while Selma, a Muslim, was reared in a much more free and easy home. ${ }^{45}$

41 N. Çiçek, "The Role of Mass Education in Nation-building in the Ottoman Empire and the Turkish Republic, 1870-1930," in Brockliss and Sheldon, Mass Education, 224-250.

42 See the chapters by Çiçek and Libal in this volume.

43 See the chapter by Wirtz in this volume.

44 See the chapter by Maksudyan in this volume.

45 See the chapter by Köksal in this volume. 
Of course, much the same points could be made about the reality of childhoods in Western states in the late nineteenth and early twentieth centuries. By 1930 all over Europe, the state might have successfully established universal and compulsory education and asserted the right to interfere in many aspects of parenting, but the family home and hearth remained the focus of childrearing outside the Soviet Union. In working-class households as well, most state initiatives continued to be met with varying degrees of resentment: teachers, midwives and Lady Bountifuls usually encountered the same suppressed hostility as the rent collector if they tried to cross the threshold. ${ }^{46}$ But the big difference in the Western world was that the creators of the new concept of childhood and their governmental supporters were working with the grain. They were heirs to a campaign waged by the churches from the era of the Reformation and Counter-Reformation to release ordinary people from the purported shackles of medieval superstition and paganism and turn them into God-fearing, moral and sober Christians. Ordinary people, however resentful, were relatively inured to external intrusion into their lives. Even parenting had come within the purview of the Calvinist consistory. ${ }^{47}$ Outside Europe, if the power of religion in the lives of ordinary people was just as great, if not greater, there had not been a comparable longstanding promotion of regeneration; individuals might choose a life of austerity but apart from occasional moments of zealousness, there had been no collective drive to eradicate sin and wipe out popular culture. As the essays in the following pages confirm, importing evolving Western ideas of childhood was never going to be easy in the Ottoman and post-Ottoman world. Modernizers who sought to effect serious change in the face of the forces of conservatism and with very limited resources were embarking on an uncertain voyage into the future.

\section{Bibliography}

Akenson, Donald H., The Irish Educational Experiment: The National System of Education in the Nineteenth Century, London: Routledge and Kegan Paul, 1970. Ariès, Philippe, Centuries of Childhood: A Social History of Family Life, translated by Robert Baldick, London: Jonathan Cape, 1962.

46 For a recent study of working-class upbringing based on some six hundred autobiographies, see Jane Humphries, Childhood and Child Labour in the Industrial Revolution (Cambridge: Cambridge University Press, 2010).

47 On the Reformation and Counter-Reformation as movements to turn the laity into good Christians, see, as an introduction, John Bossy, Christianity in the West, 1400-1700 (Oxford: Oxford University Press, 1985). 
Barron, Hester, “Changing Conceptions of the 'Poor Child': The Children's Country Holiday Fund, 1918-1939," Journal of the History of Childhood and Youth, forthcoming. Bede, Cuthbert. The Adventures of Verdant Green, Oxford: Oxford Paperbacks, 1982 [1853-1857].

Berg, Ellen, "To Become GOOD MEMBERS OF CIVIL SOCIETY and PATRIOTIC AMERICANS': Mass Education in the United States, 1870-1930," in Brockliss and Sheldon, Mass Education, 2012, 177-201.

Bossy, John, Christianity in the West, 1400-1700, Oxford: Oxford University Press, 1985. Brockliss, Laurence and Nicola Sheldon (eds), Mass Education and the Limits of State Building, c. 1870-1930, Basingstoke: Palgrave Macmillan, 2012.

Brooks, Jeffrey, When Russia Learnt to Read: Literacy and Popular Literature, 1861-1917, Princeton: Princeton University Press, 1985.

Butler, Samuel, The Way of All Flesh, Harmondsworth: Penguin, 1966 [1903], 125.

Chisick, Harvey, The Limits of Reform in the Enlightenment: Attitudes towards the Education of the Lower Classes in Eighteenth-century France, Princeton: Princeton University Press, 1981.

Çiçek, Nazan, "The Role of Mass Education in Nation-building in the Ottoman Empire and the Turkish Republic, 1870-1930," in Brockliss and Sheldon, Mass Education, 2012, 224-250.

Croall, Jonathan, Neill of Summerhill: The Permanent Rebel, London: Routledge, Kegan and Paul, 1983 .

Downs, Laura, Childhood in the Promised Land: Working-Class Movements and the Colonies de Vacances in France, 1880-1960, Durham, NC: Duke University Press, 1960.

Duff, S.E. "'Education for Every Son and Daughter in South Africa: Race, Class and the Compulsory Education Debate in the Cape Colony," in Brockliss and Sheldon, Mass Education, 2012, 261-282.

Eklof, Ben, Russian Peasant Schools: Officialdom, Village Culture and Popular Pedagogy, Berkeley: University of California Press, 1986.

Fortna, Benjamin C., Imperial Classroom: Islam, the State and Education in the Late Ottoman Empire, Oxford: Oxford University Press, 2002.

Fuchs, Rachel G., Abandoned Children: Foundlings and Child Welfare in NineteenthCentury France, Albany: SUNY Press, 1984.

Gill, Natasha, Educational Philosophy in the French Enlightenment: From Nature to Second Nature, Farnham: Ashgate, 2010.

Grenby, Matthew, The Child Reader, 1700-1840, Cambridge: Cambridge University Press, 2011.

Grew, Raymond, and Harrigan, Patrick J., School, State, and Society: The Growth of Elementary Schooling in Nineteenth-Century France: A Quantitative Analysis, Ann Arbor: University of Michigan Press, 1992.

Hall, G. Stanley, Adolescence: Its Psychology and Its Relations to Physiology, Anthropology, Sociology, Sex, Crime and Religion, New York: D. Appleton and Company, 1904. 
Harten, Han-Christian, Elementarschule und Pädagogik in der Französischen Revolution,

Munich: R. Oldenbourg, 1990.

Hendrick, Harry, Child Welfare: England, 1872-1989, London: Routledge, 1994.

Hendrick, Harry, Children, Childhood and English Society, 1880-1990, Cambridge:

Cambridge University Press, 1997.

Heywood, Colin, A History of Childhood: Children and Childhood in the West from

Medieval to Modern Times, Cambridge: Polity Press, 2001.

Humphries, Jane, Childhood and Child Labour in the Industrial Revolution, Cambridge:

Cambridge University Press, 2010.

Jackson, Louise, Child Sexual Abuse in Victorian England, London: Routledge, 2000.

Kelly, Catriona, Children's World: Growing Up in Russia, 1890-1991, New Haven: Yale

University Press, 2007.

Langford, Peter E., Vygotsky's Developments and Educational Psychology, Hove: Psychology Press, 2005.

Lowy, Ilana, “Measures, Instruments, Methods and Results': Jozefa Joteyko on Social

Reforms and Physiological Measures," in Gérald Jorland, Annick Opinel and George

Weicz (eds), Body Counts: Medical Quantification in Historical and Sociological Perspective/Quantification médicale: perspectives historiques et sociologiques, Montreal: McGill-Queen's University Press, 2005, 143-172.

Marland, Hilary, Health and Girlhood in Britain, 1874-1920, Basingstoke: Palgrave Macmillan, 2013.

Matzner, Sebastian, "Haunted by Paradise Lost:The Theme of Childhood in Eighteenth-

Century Melancholy Writing," Childhood in the Past, 1, 2008, 120-135.

McDermid, Jane, The Schooling of Girls in Britain and Ireland, 180o-19oo, Abingdon: Routledge, 2012.

Montgomery, Heather, "Unwanted Children and Adoption in England," in Laurence Brockliss and Heather Montgomery (eds), Childhood and Violence in the Western Tradition, Oxford: Oxbow Books, 2010, 83-97.

Morrison, Heidi, Modernity Comes of Age: Childhood in Early Twentieth-Century Egypt, Basingstoke: Palgrave Macmillan, forthcoming.

Mulley, Clare, The Woman who Saved the Children: A Biography of Eglantyne Jebb Founder of Save the Children, Oxford: Oneworld, 2009.

Neugebauer, Wolfgang, Absolutistischer Staat und Schulwirklichkeit in BrandenburgPreussen, Berlin: De Gruyter, 1985.

Plumb, J.H., "The New World of Children in Eighteenth-century England," Past and Present, 67, 1975, 64-95.

Pooley, Sîan “Leagues of Gentleness' and 'Column Comrades': Children's Responses to War in Late-Victorian and Edwardian England," in Lissa Paul and Rosemary Johnston (eds), Children and the Great War: 1890-1919, forthcoming. 
Proctor, Tammy M., On My Honour: Guides and Scouts in Interwar Britain, Philadelphia: American Philosophical Society, 2002.

Read, James Morgan, Atrocity Propaganda, 1914-1919, New Haven: Yale University Press, 1941.

Shahar, Shulamith, Childhood in the Middle Ages, London: Routledge 1990.

Sheldon, Nicola, "Socialising the Anti-Social Youth: Industrial Schools and Citizenship," paper presented at the Institute of Historical Studies, January 28, 2010.

Shuttleworth, Sally, The Mind of the Child: Child Development in Literature, Science and Medicine, 1840-1900, Oxford: Oxford University Press, 2010.

Stearns, Peter, Childhood in World History, Abingdon: Routledge, 2006.

Strumingher, Laura S., What Were Little Boys and Girls Made of? Primary Education in Rural France. 1830-1880, Albany: State University of New York Press, 1983.

Weisbach, Lee Shai, Child Labour Reform in the Nineteenth-century France:Assuring the Future Harvest, Baton Rouge: Louisiana State University Press, 1989.

Wright, Susannah, "Citizenship, Moral Education and the English Elementary School," in Brockliss and Sheldon, Mass Education, 2012, 21-45. 